\title{
FAKTOR-FAKTOR YANG MEMPENGARUHI LOYALITAS PETANI PADA USAHATANI PADI PANDANWANGI DI KECAMATAN GEKBRONG DAN WARUNGKONDANG KABUPATEN CIANJUR
}

\author{
Oleh: \\ Muhammad Drikeri* dan Endah Lisarini**
}

\begin{abstract}
Abstrak
Ketahanan pangan berbasis kearifan lokal pada saat sekarang masib terus digalakkan sebagai bagian dari program pangan pemerintah. Pandanwangi merupakan kearifan lokal Cianjur yang terus dikembangkan dan dilestarikan di daerah Indikasi Geografis. Dengan semakin banyaknya varietas unggul baru yang berumur lebih pendek daripada Pandanwangi, menjadi alasan banyak, petani yang enggan membudidayakannya. Penelitian ini dilakukan dengan tujuan : 1) mengetabui faktor yang membuat petani loyal terhadap usahatani padi Pandanwangi di Kecamatan Gekbrong dan Kecamatan Warungkondang Kabupaten Cianjur. 2). mengetahui faktor yang paling dominan mempengarubi loyalitas petani pada usahatani padi Pandanwangi di Kecamatan Gekbrong dan Kecamatan Warungkondang Kabupaten Cianjur. Penelitian ini merupakan penelitian deskriptif kuantitatif dengan melibatkan 50 responden petani yang selama ini tetap menanam padi Pandanwangi. Tangsapan atas pertanyaan melalui kuesioner diolab dan dianalisis menggunakan Analisis Jalur. Analisis Jalur digunakan untuk mengetahui pengaruh parsial dan simultan dari variabel eksogen yaitu Kepuasan, Kualitas, dan Citra terhadap variabel endogen yaitu Loyalitas. Hasil penelitian menunjukkan bahwa kepuasan (akan potensi hasil dan daya jual), kualitas (mumi dan beraroma khas) dan citra (merupakan kearifan local dan bersertifikasi Indikasi Geografis) merupakan faktor-faktor yang berpengarub signifikan secara simultan terrbadap loyalitas petani, namun secara parsial banya faktor citra yang berpengaruh signifikan sekaligus sebagai faktor dominan. Petani tetap loyal membudidayakan Pandanwangi karena Pandanwangi sudah bersertifikasi Indikasi Geografis dan merupakan varietas padi lokal yang memiliki sifat unggul.
\end{abstract}

Kata kunci : Kepuasan, kualitas, citra Pandanwangi

Abstract

Food security based on local wisdom at the moment is still being promoted as part of government food program. Pandanwangi is a local wisdom of Cianjur which continues to be developed and preserved in Geographical Indication area. With the increasing number of new varieties that are shorter than Pandanwangi, it is the reason many farmers are reluctant to cultivate it. This research was conducted with the aim of: 1) to know the factors that make farmers loyal to rice farming Pandanwangi in District Gekbrong and Warungkeondang District Cianjur regency. 2). know the most dominant factors affecting loyalty of farmers on rice farming Pandanwangi in District Gekbrong and District Warungkondang Cianjur. This research is a quantitative descriptive research involving 50 farmer respondents who have been planting rice paddy Pandanwangi. Responses to questions through questionnaires were processed and analyzed using Path Analysis. Path. Analysis is used to determine the partial and simultaneous effects of exogenous variables of Satisfaction, Quality, and Image to endogenous variable Loyalty. The results showed that the satisfaction (of potential yield and selling power), quality (pure and aromatic) and image (the local wisdom and certified Geographical Indication) are the factors that significantly influence the loyalty of farmers simultaneously, but only partially factor image that has a significant effect and as a dominant factor. Farmers remain loyal to cultivate Pandanwangi because Pandanwangi is already certified Geographical Indication and is a local rice varieties that have superior properties.

Key words : satisfaction, quality, image of Pandanwangi

*Alumni Mahasiswa Fakultas Sains Terapan Universitas Suryakanacana

** Dosen tetap Fakultas Sains Terapan Universitas Suryakanacana 


\section{PENDAHULUAN}

Sektor pertanian merupakan sumber kehidupan bagi sebagian besar penduduk, terutama bagi mereka yang memiliki mata pencaharian utama sebagai petani. Hal ini disebabkan Negara Indonesia merupakan negara agraris sehingga peran sektor pertanian masih merupakan sektor yang memberikan kontribusi yang cukup besar. Selain itu sektor pertanian adalah salah satu hal penting yang harus diperhatikan sebagai penyedia pangan bagi masyarakat. Peningkatan produksi yang harus seimbang dengan laju pertumbuhan penduduk dapat dicapai melalui peningkatan pengelolaan usahatani secara intensif. Usahatani adalah usaha yang dilakukan untuk memperoleh pendapatan dengan jalan memanfaatkan sumber daya alam, tenaga kerja dan modal (Soekartawi, 2002; Kadarsan, 2015). Usahatani padi merupakan salah satu usahatani yang populer di sebagian besar wilayah pertanian di Indonesia. Pengembangan varietas padi unggul baru terus digalakkan termasuk varietas padi lokal Pandanwangi dari Cianjur. Padi Pandanwangi merupakan salah satu varietas padi unggul lokal yang memiliki prospek untuk dikembangkan mengingat memiliki harga relatif tinggi, aroma khas dan rasanya yang lebih pulen sehingga diminati oleh kalangan konsumen menengah ke atas (Podesta dkk, 2009; MP3C, 2015).

Pandanwangi merupakan varietas padi indikasi geografis yang sudah disertifikasi oleh Kementerian Hukum dan HAM (MP3C, 2015). Daerah yang termasuk ke dalam Indikasi Geografis adalah kecamatan Cianjur, Cugenang, Cilaku, Warungkondang, Gekbrong, Cibeber dan Campaka. Dari ke tujuh kecamatan tersebut, Warungkondang dan Gekbrong merupakan dua kecamatan yang petaninya masih bersedia membudidayakan padi Pandanwangi (Dinas Pertanian Tanaman Pangan dan Hortikultura Kabupaten Cianjur, 2016; hasil observasi lapang tidak dipublikasikan, 2017). Umur panen Pandanwangi yang cukup lama yaitu 155 hari, perlakuan panen dan pasca panen yang berbeda dengan padi pada umumnya serta segmen pasar yang relatif terbatas menjadi alasan keengganan para petani membudidayakannya. Akan tetapi berdasarkan hasil observasi lapang, masih dijumpai petani yang tetap membudidayakan padi Pandanwangi khususnya di kecamatan Gekbrong dan Warungkondang. Hal ini yang mendasari dilakukannya penelitian ini.

Tujuan penelitian ini adalah untuk mengkaji : 1). faktor yang membuat petani loyal terhadap usahatani padi Pandanwangi di Kecamatan Gekbrong dan Kecamatan Warungkondang Kabupaten Cianjur. 2). faktor yang paling dominan mempengaruhi loyalitas petani pada usahatani padi Pandanwangi di Kecamatan Gekbrong dan Kecamatan Warungkondang Kabupaten Cianjur.

\section{TINJAUAN PUSTAKA}

Indonesia sebagai salah satu negara di dunia yang bahan pangan pokoknya berupa beras. Oleh karena itu tidak mengherankan apabila terus dilakukan penelitian dan pengembangan padi oleh sejumlah akademisi guna mendapatkan varietas padi unggul dengan potensi hasil tinggi. Plasma nutfah yang bersumber dari varietas - varietas lokal yang bersifat unggul senantiasa dikembangkan dan dilestarikan. Salah satu varietas padi lokal yang memiliki sejumlah keunggulan adalah padi Pandanwangi. Padi Pandanwangi merupakan varietas padi Javonica yang berumur panjang sekira 155 hari. Beras yang dihasilkan sangat disukai banyak orang karena aroma wangi khas beras dan kepulenannya (MP3C, 2015).

Loyal dapat diartikan tetap teguh pada kesetiaan, yaitu a) setia kepada penguasa atau pemerintah yang sah secara hukum, b) setia kepada seseorang yang berhak mendapatkan kesetiaan, c) setia kepada penyebab, yang ideal, yang biasa, objek, lembaga atau produk (Soman and Marandi, 2010). Loyalitas dapat dipengaruhi oleh beberapa faktor di antaranya adalah kepuasan (Mardalis, 2005), kualitas (Al Azzam, 2015; Lisarini, 2017) dan citra (Kotler, 2002). Nurhayati 
(2011) dalam penelitiannya mendapatkan bahwa kepuasan merupakan penyebab loyalitas walaupun tidak sekuat pengaruh kepercayaan terhadap loyalitas. Kualitas produk memberikan pengaruh tidak langsung kepada loyalitas, atau kualitas produk bersama-sama dengan bauran pemasaran lainnya dapat membangun loyalitas akan produk (Zehir et al, 2011; Bagram et al, 2012).

\section{METODE PENELITIAN}

$\begin{array}{rlr}\text { Penelitian } & \text { ini dilaksanakan di } \\ \text { kecamatan } & \text { Gekbrong dan }\end{array}$ Warungkondang kabupaten Cianjur. Penentuan kedua kecamatan tersebut berdasarkan pertimbangan sebagai dua kecamatan terbesar para petaninya masih membudidayakan padi Pandanwangi (Dinas Pertanian Tanaman Pangan dan Hortikultura Kabupaten Cianjur, 2016).

Populasi dalam penelitian ini adalah para petani yang sudah beberapa tahun terakhir ini senantiasa menanam padi Pandanwangi. Dari populasi tersebut diharapkan akan diperoleh gambaran umum karakteristik petani dan faktorfaktor yang mempengaruhi loyalitasnya pada usahatani Pandanwangi Cianjur. Dikarenakan petani yang menanam padi Pandanwangi jumlahnya cukup banyak dan berubah-ubah setiap musim tanamnya, maka jumlah populasinya tidak diketahui dengan pasti, dan hal ini menjadi dasar bagi peneliti melakukan sampling (Subagyo, 2006; Sugiyono, 2011). Sampling yang dilakukan adalah non probability sampling dengan teknik quota sampling. Dalam penelitian ini jumlah sampel sebanyak 50 responden. Jumlah sampel didasarkan pada ketentuan penggunaan metode Analisis Jalur (Path
Analysis). Dikutip dari Solimun (2002), jumlah sampel ditentukan dengan persyaratan berikut : a) Bila pendugaan parameter menggunakan metode kemungkinan maksimum, besar sampel yang disarankan adalah 100 hingga 200 dan minimum absolutnya adalah 50; b) Sebanyak 5 hingga 10 kali jumlah parameter yang ada di dalam model dan yang akan diduga; c) Sama dengan 5 hingga 10 kali jumlah variabel manifest (indikator) dari keseluruhan variabel laten. Dalam menetapkan jumlah sampel, peneliti menggunakan dasar a) yaitu minimum jumlah sampel 50.

Variabel penelitian meliputi tiga variabel bebas (exogen) dan satu variabel tergantung (endogen). Variabel eksogen terdiri dari Kepuasan $\left(\mathrm{X}_{1}\right)$, Kualitas $\left(\mathrm{X}_{2}\right)$ dan Citra $\left(\mathrm{X}_{3}\right)$ sedangkan variabel endogennya adalah Loyalitas (Y). Variabel Kepuasan diukur melalui indikator : potensi hasil sesuai harapan dan daya jual sesuai harapan. Kualitas diukur melalui indikator : potensi hasil lebih tinggi daripada VUB dan daya jual lebih tinggi daripada VUB. Variabel Citra diukur melalui indikator : sudah memiliki HAKI dan merupakan padi unggul kearifan lokal. Sementara untuk variabel endogen Loyalitas diukur melalui : tidak ingin berpindah (konsisten). Pengumpulan data primer dan sekunder dilakukan melalui observasi, wawancara, dokumentasi dan kuesioner. Data primer berupa tanggapan responden atas butirbutir pernyataan pada kuesioner. Tanggapan responden diukur dengan skala Likert berperingkat atau ordinal dari skala 1 (sangat tidak setuju), 2 (tidak setuju), 3 (cukup), 4 (setuju) sampai 5 (sangat setuju). 
Tabel 1. Operasionalisasi Variabel Penelitian

\begin{tabular}{|c|c|c|c|}
\hline $\begin{array}{l}\text { Atribut } \\
\text { Variabel }\end{array}$ & Konsep Variabel & Indikator & Skala \\
\hline $\begin{array}{c}\text { Kepuasa } \\
\mathbf{n} \\
\left(\mathrm{X}_{1}\right)\end{array}$ & $\begin{array}{l}\text { Menurut Kotler dan Armstrong (2001), } \\
\text { Kepuasan konsumen adalah sejauh mana } \\
\text { anggapan kinerja produk memenuhi } \\
\text { harapan pembeli. Lisarini (2017) } \\
\text { menyebutkan bahwa suatu kepuasan } \\
\text { merupakan hasil pengaruh dari kualitas, } \\
\text { dan kepuasan akan berpengaruh terhadap } \\
\text { loyalitas. }\end{array}$ & $\begin{array}{l}\text { 1. Potensi hasil } \\
\text { sesuai harapan. } \\
\text { 2. Daya jual sesuai } \\
\text { harapan. }\end{array}$ & \\
\hline $\begin{array}{c}\text { Kualitas } \\
\left(\mathrm{X}_{2}\right)\end{array}$ & $\begin{array}{l}\text { Menurut Gerson (2004), kualitas adalah } \\
\text { apapun yang dianggap pelanggan sebagai } \\
\text { mutu. }\end{array}$ & $\begin{array}{l}\text { 1. Potensi hasil } \\
\text { tinggi lebih dari } \\
\text { VUB. } \\
\text { 2. Daya jual tinggi } \\
\text { lebih dari VUB. }\end{array}$ & Ordinal \\
\hline $\begin{array}{l}\text { Citra } \\
\left(X_{3}\right)\end{array}$ & $\begin{array}{l}\text { Menurut Dewi (2008) citra adalah persepsi } \\
\text { tentang merek yang merupakan refleksi } \\
\text { memori konsumen akan asosiasinya pada } \\
\text { merek tersebut. }\end{array}$ & $\begin{array}{l}\text { 1. Sudah } \\
\text { memiliki HAKI } \\
\text { atau hak cipta. } \\
\text { 2. Padi unggul } \\
\text { kearifan lokal. }\end{array}$ & \\
\hline $\begin{array}{l}\text { Loyalitas } \\
\text { (Y) }\end{array}$ & $\begin{array}{l}\text { Mardalis (2005) loyalitas merupakan } \\
\text { kondisi dimana orang tersebut } \\
\text { mempunyai sikap positif terhadap suatu } \\
\text { produk, mempunyai komitmen pada } \\
\text { produk tersebut. }\end{array}$ & $\begin{array}{l}\text { 1. Tidak ingin } \\
\text { berpindah } \\
\text { (konsisten). }\end{array}$ & \\
\hline
\end{tabular}

Rincian dari variabel-variabel tersebut dapat dilihat pada Tabel 1. mengenai operasinalisasi variabel penelitian. Untuk mengetahui pengaruh parsial maupun simultan dari variabel bebas (eksogen) terhadap variabel tergantungnya (endogen), dilakukan analisis jalur. Sebelumnya, data yang diolah merupakan data lapang yang sudah diuji validitas, reliabilitasnya dan normalitasnya sehingga layak untuk diolah lanjut. Data dinyatakan valid apabila nilai $\mathrm{r}$ hitung $>$ cut off 0.300 . Data dinyatakan reliabel jika nilai $\mathrm{r}$ hitung $>$ nilai cut off 0.600 (Zulganef, 2006) dan data dinyatakan berdistribusi normal apabila nilai K-S > 0.500 (Ghozali, 2011). Data yang memenuhi kelayakan ketiga uji tersebut dinyatakan dapat diolah lanjut ke analisis Jalur.

\section{HASIL DAN PEMBAHASAN}

Pengumpulan data kuantitatif dilakukan terhadap 50 responden petani penanam padi Pandanwangi di kecamatan Gekbrong dan Warungkondang Cianjur. Karakteristik petani yang menjadi responden dalam penelitian ini meliputi : jenis kelamin, umur, asal daerah, status pendidikan, status pernikahan, tingkat pendapatan, status kepemilikan lahan, lamanya telah berusahatani padi dapat dijelaskan pada Tabel 2 berikut ini. 


\begin{tabular}{|c|c|c|c|c|c|c|c|}
\hline \multicolumn{8}{|c|}{ Tabel 2. Karakteristik Responden } \\
\hline $\begin{array}{c}\text { Jenis } \\
\text { Kelamin }\end{array}$ & Jumlah & $\begin{array}{l}\text { Umur } \\
\text { (tahun) }\end{array}$ & Jumlah & $\begin{array}{c}\text { Asal } \\
\text { Daerah }\end{array}$ & Jumlah & $\begin{array}{l}\text { Status } \\
\text { Kepemili } \\
\text { kan }\end{array}$ & Jumlah \\
\hline Pria & 43 & $<19$ & 0 & $\begin{array}{l}\text { Kp. } \\
\text { Nangleng }\end{array}$ & 10 & Pemilik & 12 \\
\hline Wanita & 7 & $19-59$ & 45 & $\begin{array}{l}\text { Kp. } \\
\text { Sukaratu }\end{array}$ & 13 & $\begin{array}{l}\text { Penggara } \\
\text { p }\end{array}$ & 23 \\
\hline & & $>59$ & 5 & $\begin{array}{l}\text { Kp. } \\
\text { Tegalega }\end{array}$ & 8 & $\begin{array}{l}\text { Pemilik } \\
\text { dan } \\
\text { penggara } \\
\text { p }\end{array}$ & 14 \\
\hline & & & & $\begin{array}{l}\text { Kp. } \\
\text { Padakati }\end{array}$ & 10 & & \\
\hline & & & & $\begin{array}{l}\text { Kp. } \\
\text { Lojikolot }\end{array}$ & 9 & & \\
\hline \multicolumn{8}{|c|}{ Tabel 2. Karakteristik responden (lanjutan) } \\
\hline $\begin{array}{l}\text { Pendidik } \\
\text { an }\end{array}$ & Jumlah & $\begin{array}{c}\text { Status } \\
\text { Pernika } \\
\text { han }\end{array}$ & Jumlah & $\begin{array}{c}\text { Pendapata } \\
\text { n per } \\
\text { Bulan (Rp) }\end{array}$ & Jumlah & $\begin{array}{c}\text { Lama } \\
\text { Menanam } \\
\text { (tahun) }\end{array}$ & Jumlah \\
\hline $\begin{array}{l}\text { Tidak } \\
\text { tamat } \\
\text { SD }\end{array}$ & 0 & $\begin{array}{l}\text { Belum } \\
\text { menika } \\
\text { h }\end{array}$ & 0 & $<0.5 \mathrm{jt}$ & 0 & $<10$ & 11 \\
\hline SD & 30 & $\begin{array}{l}\text { Menika } \\
\text { h }\end{array}$ & 48 & $0.5-1 \mathrm{jt}$ & 0 & $10-25$ & 38 \\
\hline SMP & 18 & $\begin{array}{l}\text { Janda / } \\
\text { Duda }\end{array}$ & 2 & $>1-2 \mathrm{jt}$ & 17 & $>25$ & 1 \\
\hline SMA & 2 & & & $2 \mathrm{jt}$ & 33 & & \\
\hline S1 & 0 & & & & & & \\
\hline
\end{tabular}

Dari Tabel 2 dapat dilihat bahwa terdapat 43 atau $86 \%$ responden pria dan 7 atau 14\% responden wanita. Keadaan ini menjelaskan bahwa profesi petani memang lebih banyak dilakukan oleh pria selain menuntut tenaga yang kuat, petani pria juga bertanggungjawab sebagai kepala keluarga pencari nafkah. Dari segi usia, terbanyak pada usia produktif 19 - 59 tahun sebanyak 45 orang (90\%). Asal daerah responden keseluruhannya termasuk ke dalam kecamatan Warungkondang yang merupakan salah satu kecamatan indikasi geografis. Sebanyak 46\% responden merupakan petani penggarap. Walaupun sebagai penggarap, $\mathrm{p}$ (ara petani diberi kebebasan menentukan varietas padi yang ditanam. Terbanyak dari responden berpendidikan SD $(60 \%)$ dan sudah menikah sebanyak $96 \%$. Penghasilan di atas 2 juta rupiah per bulan berada pada jumlah terbanyak yaitu $66 \%$ dan pengalaman berusahatani padi terbanyak sebesar $76 \%$ selama $10-25$ tahun. Walaupun tingkat pendidikan responden hanya lulus SD namun pengalaman bertaninya sudah cukup lama dan penghasilan per bulan mereka cukup besar.

Data tanggapan responden dianalisis secara deskriptif terlebih dahulu untuk mengetahui tanggapan rata-rata responden terhadap faktor-faktor yang mempengaruhi loyalitas petani menanam padi Pandanwangi. Skor rata-rata tanggapan dikategorikan ke dalam klas kategori Sangat Setuju $(4.2-5.0)$, Setuju (3.4 - 4.1), Kurang Setuju (2.6 - 3.3), Tidak Setuju $(1.8-2.5)$ dan Sangat Tidak Setuju $(1.0$ - 1.7). Secara deskriptif dapat diketahui bahwa tanggapan responden terhadap kepuasan, kualitas, citra dan loyalitas dapat diringkas pada tabel 3 berikut ini. 
Tabel 3. Rata-rata tanggapan responden terhadap kepuasan, kualitas, citra dan loyalitas

\begin{tabular}{|c|c|c|c|c|c|}
\hline $\begin{array}{l}\text { Atribut dan } \\
\text { dimensi }\end{array}$ & $\begin{array}{l}\text { Skor } \\
\text { rata- } \\
\text { rata }\end{array}$ & Kategori & Atribut dan dimensi & $\begin{array}{l}\text { Skor } \\
\text { rata- } \\
\text { rata }\end{array}$ & Kategori \\
\hline Kepuasan $\left(\mathrm{X}_{1}\right)$ & & & Citra $\left(\mathrm{X}_{3}\right)$ & & \\
\hline $\begin{array}{l}\text { Kemampuan } \\
\text { tumbuh benih bagus } \\
\text { sesuai harapan. }\end{array}$ & 4.76 & $\begin{array}{l}\text { Sangat } \\
\text { Setuju }\end{array}$ & $\begin{array}{l}\text { Pandanwangi varietas } \\
\text { local Cianjur }\end{array}$ & 4.86 & $\begin{array}{l}\text { Sangat } \\
\text { Setuju }\end{array}$ \\
\hline $\begin{array}{l}\text { Kecacatan hasil } \\
\text { panen minim sesuai } \\
\text { harapan. }\end{array}$ & 4.76 & $\begin{array}{l}\text { Sangat } \\
\text { Setuju }\end{array}$ & $\begin{array}{l}\text { Pandanwangi } \\
\text { kebanggaan Kabupaten } \\
\text { Cianjur }\end{array}$ & 4.86 & $\begin{array}{l}\text { Sangat } \\
\text { Setuju }\end{array}$ \\
\hline $\begin{array}{l}\text { Hasil panen sesuai } \\
\text { harapan }\end{array}$ & 4.62 & $\begin{array}{l}\text { Sangat } \\
\text { Setuju }\end{array}$ & $\begin{array}{l}\text { Tidak ada yang } \\
\text { mengakui Pandanwangi } \\
\text { bukan asal Cianjur }\end{array}$ & 4.86 & $\begin{array}{l}\text { Sangat } \\
\text { Setuju }\end{array}$ \\
\hline $\begin{array}{l}\text { Harga jual padi } \\
\text { tinggi }\end{array}$ & 4.12 & Setuju & $\begin{array}{l}\text { Pandanwangi harus } \\
\text { dilestarikan. }\end{array}$ & 4.94 & $\begin{array}{l}\text { Sangat } \\
\text { Setuju }\end{array}$ \\
\hline $\begin{array}{l}\text { Tingkat penjualan } \\
\text { sesuai harapan }\end{array}$ & 3.18 & Setuju & $\begin{array}{lr}\text { Alasan menanam } \\
\text { P.andanwangi } \\
\text { pelestarian }\end{array}$ & 4.68 & $\begin{array}{l}\text { Sangat } \\
\text { Setuju }\end{array}$ \\
\hline $\begin{array}{lr}\text { Segmen } & \text { pasar } \\
\text { Pandanwangi } & \text { sesuai } \\
\text { harapan } & \end{array}$ & 4.1 & Setuju & $\begin{array}{l}\text { Merasa tidak ikut andil } \\
\text { dalam pelestarian jika } \\
\text { tidak menanam } \\
\text { Pandanwangi }\end{array}$ & 4.52 & $\begin{array}{l}\text { Sangat } \\
\text { Setuju }\end{array}$ \\
\hline Kualitas $\left(\mathbf{X}_{2}\right)$ & & & Loyalitas $\left(\mathrm{X}_{4}\right)$ & & \\
\hline \multirow[t]{2}{*}{$\begin{array}{l}\text { Kemampuan } \\
\text { tumbuh benih lebih } \\
\text { dari VUB }\end{array}$} & 4.76 & $\begin{array}{l}\text { Sangat } \\
\text { Setuju }\end{array}$ & $\begin{array}{l}\text { Potensi hasil sesuai } \\
\text { harapan }\end{array}$ & 4.3 & $\begin{array}{l}\text { Sangat } \\
\text { Setuju }\end{array}$ \\
\hline & 4.76 & $\begin{array}{l}\text { Sangat } \\
\text { Setuju }\end{array}$ & Kualitas lebih dari VUB & 4.64 & $\begin{array}{l}\text { Sangat } \\
\text { Setuju }\end{array}$ \\
\hline $\begin{array}{l}\text { Hasil panen lebih } \\
\text { baik dari VUB }\end{array}$ & 4.68 & $\begin{array}{l}\text { Sangat } \\
\text { Setuju }\end{array}$ & $\begin{array}{l}\text { Pandanwangi sebagai } \\
\text { kearifan lokal }\end{array}$ & 4.54 & $\begin{array}{l}\text { Sangat } \\
\text { Setuju }\end{array}$ \\
\hline $\begin{array}{l}\text { Harga jual lebih dari } \\
\text { VUB }\end{array}$ & 4.12 & Setuju & & & \\
\hline $\begin{array}{l}\text { Tingkat penjualan } \\
\text { lebih dari VUB }\end{array}$ & 3.16 & $\begin{array}{l}\text { Kurang } \\
\text { Setuju }\end{array}$ & & & \\
\hline $\begin{array}{lr}\text { Segmen } & \text { pasar } \\
\text { Pandanwangi } & \text { sesuai } \\
\text { harapan } & \\
\end{array}$ & 4.12 & Setuju & & & \\
\hline
\end{tabular}

Dari tabel 3 dapat disimpulkan bahwa responden pada umumnya menyatakan setuju sampai sangat setuju bahwa padi Pandanwangi memberikan kepuasan karena potensi hasil dan harga jualnya yang lebih tinggi dibandingkan dengan VUB, kualitasnya lebih baik dibandingkan dengan VUB dalam hasil panen dan penjualannya serta memiliki citra sebagai varietas padi kearifan lokal Cianjur. Tanggapan sangat setuju dinyatakan oleh responden terhadap indicator loyalitas petani pada
Pandanwangi. Alasan loyalitas responden karena Pandanwangi mempunyai potensi hasil dan kualitas yang lebih baik disbanding VUB serta merupakan kearifan lokal Cianjur.

Selanjutnya untuk menjawab tujuan penelitian 1 dan 2, dilakukan pengolahan dan analisis kuantitatif dengan menggunakan Path Analysis terhadap data yang sudah memenuhi validitas, reliabilitas dan normalitas data seperti yang ditunjukkan pada table 4 dan 5. Data-data yang sudah memenuhi syarat valid, 
reliabel dan berdistribusi normal, maka data dapat diolah lanjut sesuai dengan yang dipersyaratkan (Sugiyono, 2009; Zulganef, 2006).

Dari Tabel 4. diketahui bahwa ke empat variabel penelitian telah memenuhi syarat validitas dan reliabilitas sehingga akan dilanjutkan dengan uji normalitas

data. Variabel penelitian yang valid

menunjukkan bahwa butir-butir pernyataan yang merupakan indikator variabel dapat mengukur variabel laten bebas maupun variabel laten tergantung. Sementara variabel penelitian yang reliabel menjelaskan bahwa responden dalam memberikan tanggapan atas pernyataanpernyataan bersifat ajeg.
Pandanwangi yang lebih baik dibanding VUB dan citra Pandanwangi sebagai kearifan lokal Cianjur. Selanjutnya untuk mengetahui faktor yang paling dominan mempengaruhi loyalitas petani pada usahatani padi Pandanwangi di Kecamatan Gekbrong dan Kecamatan Warungkondang Kabupaten Cianjur dilanjutkan dengan pengujian secara simultan dan parsial.

Untuk mengetahui pengaruh simultan dari variabel bebas terhadap variabel tergantung dilakukan uji F, sedangkan untuk mengetahui pengaruh parsial masing-masing variabel bebas terhadap variabel terikat dilakukan uji t.

Tabel 4. Hasil uji validitas dan reliabilitas

\begin{tabular}{lllllll}
\hline No & $\begin{array}{l}\text { Variabel } \\
\text { Penelitian }\end{array}$ & $\begin{array}{l}\text { Corrected } \\
\text { Item-Total } \\
\text { Correlation }\end{array}$ & $\begin{array}{l}\text { Cut } \\
\text { off }\end{array}$ & $\begin{array}{l}\text { Cronbach's } \\
\text { Alpha If }\end{array}$ & $\begin{array}{l}\text { Cut } \\
\text { Item }\end{array}$ & Keterangan \\
Deleted & & \\
\hline $\mathbf{1}$ & Kepuasan $\left(\mathrm{X}_{1}\right)$ & 0.887 & 0.300 & 0.746 & 0.600 & Valid, reliabel \\
\hline $\mathbf{2}$ & Kualitas $\left(\mathrm{X}_{2}\right)$ & 0.874 & 0.300 & 0.753 & 0.600 & Valid, reliabel \\
\hline $\mathbf{3}$ & Citra $\left(\mathrm{X}_{3}\right)$ & 0.612 & 0.300 & 0.863 & 0.600 & Valid, reliabel \\
\hline $\mathbf{4}$ & Loyalitas $(\mathrm{Y})$ & 0.590 & 0.300 & 0.883 & 0.600 & Valid, reliabel
\end{tabular}

Tabel 5. Uji Normalitas

\begin{tabular}{llrrrr}
\multicolumn{2}{c}{ One-Sample Kolmogorov-Smirnov Test } & & \\
N & & total_x1 & total_x2 & total_x3 & total_y \\
Normal Parametersa,,b & Mean & 50 & 50 & 50 & 50 \\
& Std. Deviation & 25.54 & 25.60 & 28.72 & 13.48 \\
Most Extreme & Absolute & .418 & 2.399 & 1.785 & 1.266 \\
Differences & Positive & .112 & .106 & .322 & .179 \\
& Negative & -.112 & .101 & .237 & .128 \\
Kolmogorov-Smirnov Z & & .789 & .106 & -.322 & -.179 \\
Asymp. Sig. (2-tailed) & .562 & .625 & .279 & 1.269 \\
a. Test distribution is Normal. & & & .000 & .080 \\
b. Calculated from data. & & & & &
\end{tabular}

Data yang berdistribusi normal dapat digunakan untuk menjelaskan gambaran dari suatu populasi atau menarik kesimpulan yang berlaku secara umum. Setelah data melalui uji validitas, reliabilitas dan normalitas, maka dapat dijawab tujuan penelitian 1. Faktor-faktor yang membuat petani loyal menanam padi Pandanwangi adalah kepuasan akan potensial hasil yang lebih tinggi disbanding VUB, kualitas
Hasil masing-masing uji tampak pada Tabel 6 dan Tabel 7 berturut-turut.

Dari hasil uji F dapat diketahui bahwa pengaruh variabel independen (kepuasan, kualitas, citra) berpengaruh signifikan secara simultan terhadap variabel dependen loyalitas. Hasil ini sebagai jawaban dari tujuan pertama penelitian. Bahwa loyalitas sangat dipengaruhi oleh kepuasan, kualitas dan citra. Hasil ini dapat menjelaskan bahwa 
petani tetap loyal menanam padi Pandanwangi dengan alasan bahwa petani merasa puas akan potensi hasil, tingkat penjualan beras Pandanwangi yang lebih baik dibandingkan dengan VUB, kualitas dan citranya sebagai kearifan lokal Cianjur.

Hasil uji F (Tabel 6) menunjukkan bahwa variabel kepuasan, kualitas dan citra

berpengaruh secara simultan terhadap loyalitas. Sebaliknya akan dilihat pengaruh secara parsial variabel independen terhadap variabel dependen melalui uji $\mathrm{t}$ (Tabel 7). parsial dan simultan dapat dilihat dalam model analisis jalur seperti pada Gambar 1. Untuk menggambarkan Diagram Jalur, perlu dihitung terlebih dahulu error model. Besarnya error model adalah sebagai berikut :

Langkah pertama adalah penghitungan koefisien determinasi. Penghitungan koefisien determinas $\left(\mathrm{R}^{2}\right)$ dilakukan melalui persamaan berikut.

Tabel 6. Uji F untuk mengetahui pengaruh simultan

\begin{tabular}{|c|c|c|c|c|c|c|}
\hline \multirow{2}{*}{\multicolumn{2}{|c|}{ Model }} & \multicolumn{3}{|c|}{ ANOVA $^{b}$} & \multirow[b]{2}{*}{$\mathrm{F}$} & \multirow[b]{2}{*}{ Sig } \\
\hline & & $\begin{array}{l}\text { Sum of } \\
\text { Squares }\end{array}$ & Df & Mean Square & & \\
\hline \multirow[t]{3}{*}{1} & Regression & 31,150 & 3 & \multirow{3}{*}{$\begin{array}{r}10,383 \\
1,029\end{array}$} & 10,091 & \multirow[t]{3}{*}{, $000^{a}$} \\
\hline & Residual & 47,330 & 46 & & & \\
\hline & Total & 78,480 & 49 & & & \\
\hline \multicolumn{6}{|c|}{$\begin{array}{l}\text { a. Predictors: (Constant), TOTAL_X3, TOTAL_X2, TOTAL_X1 } \\
\text { b. Dependent Variable: TOTAL Y }\end{array}$} & \\
\hline
\end{tabular}

Tabel 7. Hasil uji T untuk mengetahui pengaruh parsial

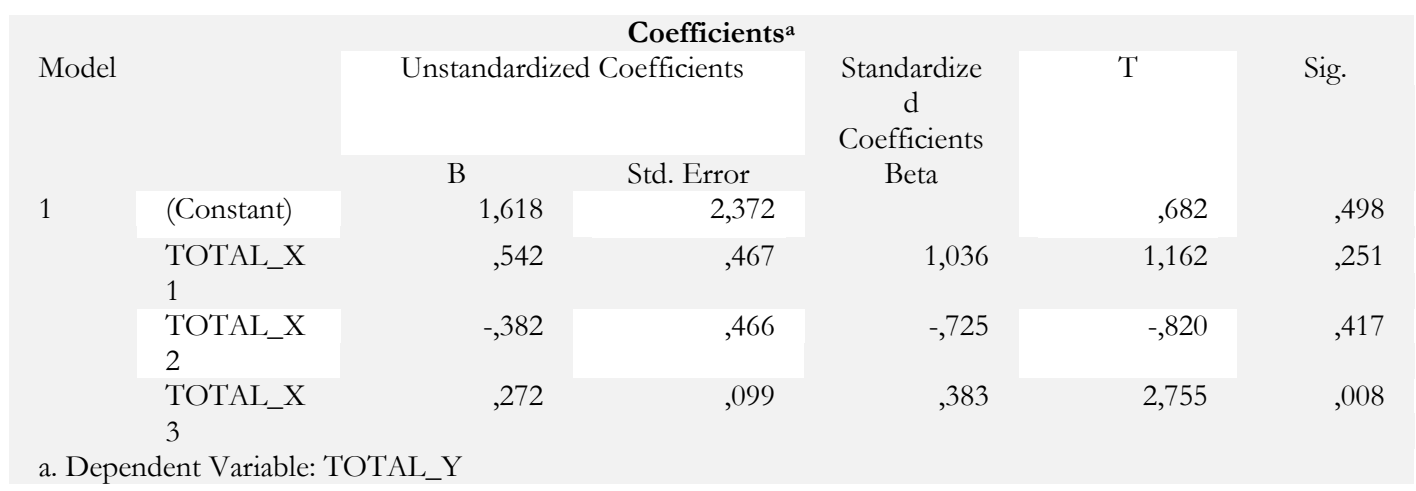

Dari hasil uji t dapat dijelaskan bahwa hanya satu variabel independen yang berpengaruh signifikan secara parsial terhadap variabel dependen. Variabel independen tersebut adalah Citra $\left(\mathrm{X}_{3}\right)$ terhadap loyalitas (Y). Keadaan ini menunjukkan bahwa petani loyal pada usahatani padi Pandanwangi dipengaruhi oleh citra dari Pandanwangi itu sendiri. Para petani mempunyai tujuan untuk melestarikan Pandanwangi sebagai varietas padi lokal yang sudah memiliki sertifikasi Indikasi Geografis. Pengaruh
Koefisien deteminasi :

$$
\begin{aligned}
\mathrm{R}^{2} & =1-\mathrm{P}^{2} \\
& =1-0,396^{2} \\
& =1-0,157 \\
& =0,843
\end{aligned}
$$

Penghitungan error model lintasan jalur sebagai berikut :

$$
\begin{aligned}
\text { Pei } & =\sqrt{1}-R^{2} \\
& =\sqrt{1}-0,397 \\
& =\sqrt{0,157} \\
& =0,396
\end{aligned}
$$

Selanjutnya dapat dibuat Diagram Jalur seperti pada Gambar 1. 


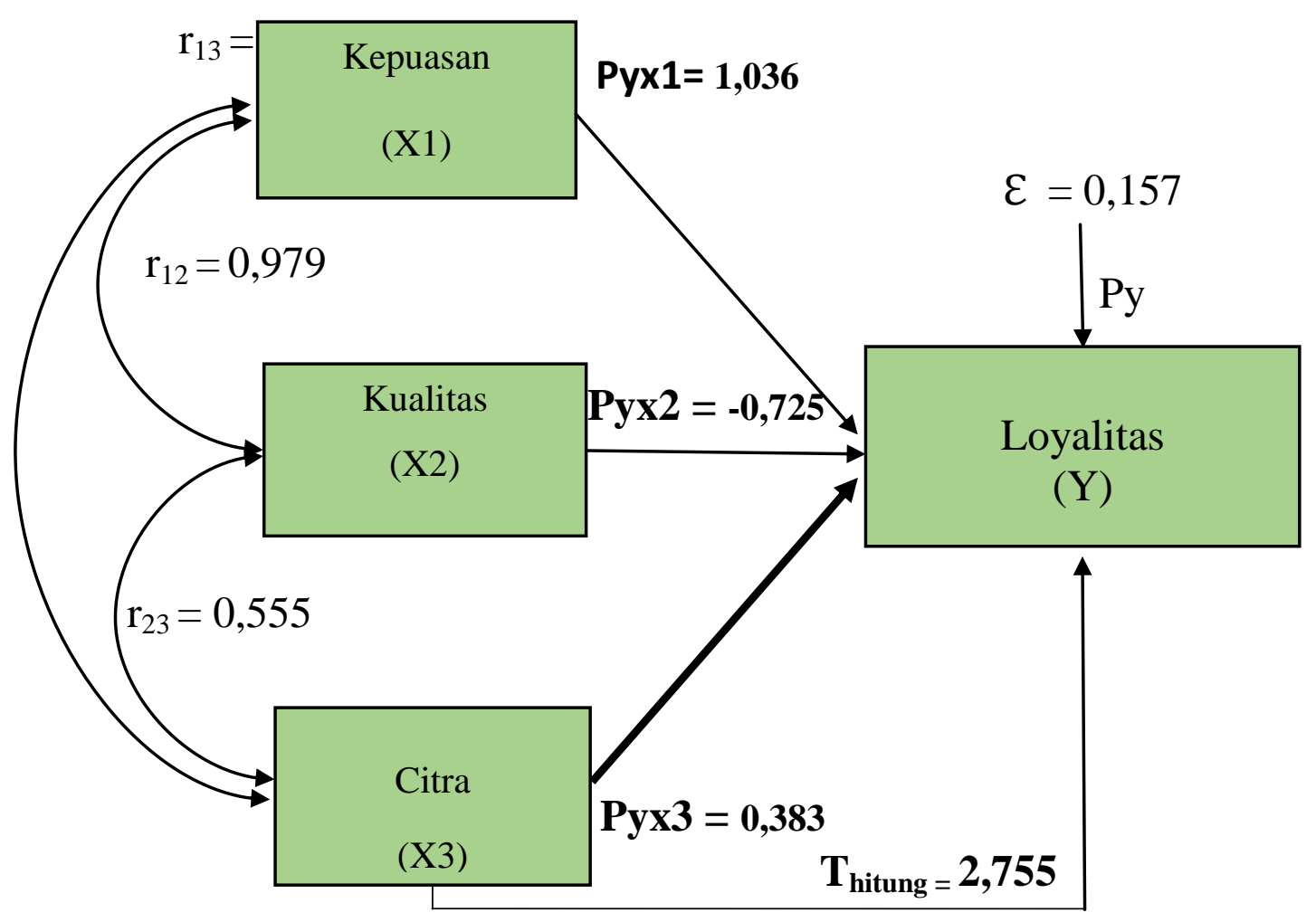

Gambar 1. Pengaruh kepuasan, kualitas dan citra terhadap loyalitas petani.

Besarnya koefisien determinasi atau $\mathrm{R}^{2}$ adalah 0.843 . Hasil ini menjelaskan bahwa sebesar $84.3 \%$ variabel dependen (loyalitas) dipengaruhi oleh keragaman variabel independen (kepuasan, kualitas dan citra), sementara sebesar $15.7 \%$ loyalitas dipengaruhi oleh hal-hal lain yang tidak diteliti pada penelitian ini.

\section{KESIMPULAN}

Dari pembahasan di atas, dapat disimpulkan bahwa :

1. Terdapat pengaruh secara simultan dari variabel bebas kepuasan, kualitas dan citra terhadap variabel tergantung (loyalitas). Pengaruh parsial hanya ditunjukkan dari variabel citra terhadap loyalitas namun variabel kepuasan dan kualitas berpengaruh tidak signifikan.
2. Variabel citra merupakan faktor yang paling dominan mempengaruhi loyalitas.

\section{DAFTAR PUSTAKA}

Bagram, Mohammad and Khan, S. 2012. "Attaining Customer Loyalty! The Role of Consummer Attitude and Consummer Behaviour". Journal of International Review of Management and Business Research. Vol. 1. Issue 1.

Dewi, 2008. "Pengarub Kepemilikan Managerial, Kepemilikan Institusional, Kebijakan Hutang, Profitabilitas dan Ukuran Perusabaan Terhadap Kebijakan Dividen”. Jurnal Bisnis dan Akuntansi. 
Dinas Pertanian Tanaman Pangan dan Hortikultura Kabupaten Cianjur, 2016. Luas Lahan Sentra Produksi Padi Pandanwangi di Kabupaten Cianjur.

Gerson, R. F, 2004. Mengukur Kepuasan Pelanggan, Jakarta.

Ghozali, Imam, 2009. Aplikasi Analisis Multivariate Dengan Program SPSS. Badan Penerbit Universitas Diponegoro.

Kadarsan, 2015. Analisis Usahatani Cabai Merah Besar (Studi Kasus Di Desa Semambung, Kecamatan Kanor, Kabupaten Bojonegoro, Provinsi Jawa Timur). Fakultas Pertanian Universitas Bojonegoro, Bojonegoro.

http:// ejournalunigoro.com/sites $\angle$ default/files/Jurnal $\% 20 \mathrm{Pak}^{0} \% 20$ Darsan 0.pdf

Kotler, Amstrong, 2002. Prinsip-prinsip pemasaran, Edisi keduabelas, Jilid 1. Erlangga, Jakarta.

Kotler, Philip dan Amstrong, Gary, 2001. Marketing Management. Milolenium Edition. Prentice Hall International, Inc. New Jersey.

Lisarini, 2017. Kualitas Produk, Komunikasi Pemasaran dan Luaran Saluran Distribusi Pemasaran Beras Pandanwangi Untuk Menciptakan Kepercayaan Konsumen Serta Implikasinya Pada Loyalitas Konsumen Di Wilayah Pemasaran Jawa Barat dan Jakarta. Disertasi, Program Doktor Ilmu Manajemen, Program Pasca Sarjana Universitas Pasundan Bandung.

Mardalis, Ahmad, 2005. Meraih Loyalitas

Pelanggan. Skripsi, Fakultas

Ekonomi Universitas

Muhammadiyah Surakarta.
Nur Hayati. 2011. "The Effect of Customer Satisfaction, Customer Trust on Customer Loyalty of The Card Users of PT. Indosat Tbk". Proceedings of The $1 \mathrm{st}$ International Conference on Information Systems for Business Copetitiveness.

Podesta, Rahmina, 2009. Pengarub penggunaan benih sertifikat terhadap efisiensi dan pendapatan usabatani Padi Pandan Wangi. Fakultas Ekonomi dan Manajemen, Institut Pertanian Bogor, Bogor.

Soekartawi, 2002. Analisis Usahatani. UI Press, Jakarta.

Solimun, 2002. Struktural Equations Modelling (SEM). Lisrel dan Hines, Fakultas MIPA. Universitas Brawijaya, Malang.

Soman, D. and Marandi, S.N. 2010. Managing Customer Value. One stage at a time. World Scientific. University of Toronto, Canada.

Sugiyono, 2011. Metode Penelitian Kuantitatif Kualitatif Dan R\&D. Alfabeta, Bandung.

Sugiyono, 2009. Memahami Penelitian Kualitatif. Alfabeta, Bandung.

Zehir, C.; Sahin, A.; Kitapci, H.; Ozsahin, M. 2011. "The Effect of Brand communication and Service Quality In Building Brand Loyalty Through Brand Trust; The Empirical Research On Global Brands". Journal of Procedia Social and Behavioral Sciences 24 (2011) 1218 - 1231.

Zulganef. 2006. Pemodelan Persamaan Struktural dan Aplikasinya Menggunakan Amos 5. Bandung: Pustaka. 